of professional art of singing in which approbation of new ideas, new technology, creative theme is carried out on the basis of classical vocal art covering through aria genre chamber as well as opera singing, which historically co-exist in close connection on the opera stage. And this genetic factor of vocal training corrects teaching methods in a music high school the status of which is determined by the existence of a relevant course (along with philosophy, history of music and composition) in total number of disciplines of a music high school.

Keywords: the aria, a vocal, teaching methodology at the higher school, the opera, belcanto.

Стаття надійцла до редакції 04.05.2016

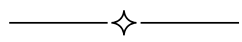

УДК $78.03+786.2$

\title{
Чжу Сяоле
}

\section{ФОРТЕПІАННИЙ ЦИКЛ Ф. ЛІСТА «РІЗДВЯНА ЯЛИНКА»: НОВА КОНЦЕПЦІЯ ДИТЯЧОЇ МУЗИКИ}

\begin{abstract}
У статті виявляються смислові пласти фортепіанного циклу Ф. Ліста «Різдвяна ялинка» в аспектах «відкриття дитинства», музичної Різдвіяни, мовно-композиторських, композиційних та духовно-філософських засад, що дозволяє виявити низку особливих властивостей форми-змісту цикла, а також спонукає до аналізу музичного матеріалу з позицій амбівалентністі сакрального/театрально-ігрового. Останнє відтворює цілісність дитячого світосприйняття, яке вдалося зберегти умудреному митцю - Ф. Лісту - до кінця життя.
\end{abstract}

Ключові слова: фортепіанний цикл для дітей, «відкриття дитинства», романтизм, Ф. Ліст, різдвяна тема в музиці.

До моменту написання циклу з дванадцяти п’єс «Різдвяна ялинка» (1874-1876) великий композитор і піаніст (а також - диригент, публіцист, музикознавець, викладач, громадський діяч, культовий персонаж та... особа священного сану, що також не можна обійти увагою) Ференц Ліст - вже автор більшості своїх найвідоміших, перш за все, віртуозно-концертних творів. Звернення зрілого, визнаного композитора, «композитора-мислителя», «композитора-філософа», як обгрунтовано його називають дослідники, однієї з найосвіченіших й універсальних фігур на горизонті художньої історії Європи, митця-монаха - до дитячого музичного формату у фортепіанному циклі «Різдвяна ялинка» вказує на цілісність творчої та людської особистос- 
ті митця з неодмінним для вказаної якості компонентом «дитячості» як чистоти, щирості, позитивної емпатії. Але даний «дитячий» цикл все ж таки відрізняється, на наш погляд, від подібної музичної літератури епохи як дещо більш ускладненими техніко-піаністичними вимогами («недитячою» кількістю знаків - від 6 дієзів до 5 бемолів, швидкими темпами аж до Molto vivace з октавно-акордовою технікою тощо), так і більш вираженою концептуальністю подання «образу світу», виявленням його цілісності (у тому числі виховного спрямування, що є невід'ємною частиною творів для дітей). Отже дитина-виконавець тут має бути не початківцем (крім деяких номерів, особливо 3 вербальними текстами). Відомо, що у дітей досить рано утворюється власний «образ світу» - а наскільки він виявиться цілісним, залежить від дорослих, які оточують дитину. Тому невипадково композитор пропонує для дитячого циклу, присвяченого, до речі, найважливішій людині у його житті, онуці Даніелі Бюлов, тему народження Христа. В циклі задіяні різні ідейні, художні та буттєві пласти цієї теми: і свято Різдва з неминучими подарунками, танцями, таємничо-дивною атмосферою (храму і дому) та іншими святковими обставинами; і біблійна історія цього свята у іiї історико-хронологічному, містеріальному та виховному аспектах, з відчуттям Радості й Таїнства Події; і найцікавіший суто музичний ракурс, пов'язаний з техніко-технологічними завданнями піаніста, звукобарвистим забарвленням імпресіоністичного толку, а також інтерпретативним концептом музичного подання вказаної теми з огляду на дитяче сприйняття і виявлення. Власне розкриттю цих смислових інтерпретативних пластів у фортепіанному циклі Ф. Ліста «Різдвяна ялинка» і присвячена дана стаття.

Вже від другої половини 1840-х років (другий період творчості) загальний тонус музики Ліста, націленої, як відомо, у перспективу відкриття нових горизонтів музичного мистецтва другої половини XIX століття, зазнає істотних концептуальних змін. Поруч з розробкою образності, позначеної ще Гете поняттям «мефісто», можна відзначити й більш спокійні, стримано-врівноважені, мудро-логічні, навіть духовно-релігійні, інтенції (які не заважають Лістові залишатися романтиком «у всій красі»). Свій перший духовний твір, «Tantum Ergo» (католицький гімн перед Святими Дарами), Ліст написав ще у 11 років (зараз вважається загубленим); у 1834 композитор пише есе «Про церковну музику майбутнього», де відтворює свої ідеї щодо докорінного перетворення культового мистецтва. Від середини 1840 pp. Ліст повертається до духовної тематики: «Ave Maria» для хору і op- 
кестру, «Pater Noster» для чоловічого хору і органу (1846), «Благословення Бога наодинці» (1848), а від 1850-х - духовні жанри привертають увагу митця постійно: Псалми (1855), «Естергомська меса», симфонія «Данте» (1856) з хором Magnificat; в 1859 р. Ліст перериває роботу над симфонічною поемою «Прометей» на користь «Псалому № 13», який рветься «3 глибини серця». Перебування ж у «серці» католицтва - Римі (від 1861) - ознаменувалося цілою низкою величних духовних творів: ораторії «Легенда про святу Слизавету» (1862 р.) i «Христос» (1866 р.); меси - «Хоральна» (1865) і «Угорська коронаційна» (1867р.); «Видіння Єзекіїля», «Stabat Mater» (1866), «Реквієм» (1868), «Гімн святої Марії» (1869); легенда «Свята Цецилія» (1874), «Хресний шлях» для хору з органом (1879); низка органних творів (у т. ч. «Gebet» - «Молитва», 1879, для органу та для сопрано і фортепіано); «Хресна путь» для хору з органом (1879); ораторія «Легенда про святого Станіслава» (не закінчена). Серед названих творів - «світські культові» опуси, які втілюють піднесені сторони життя («Данте», «Псалом № 13»), і власне церковна музика, як то меси та ораторії. Ораторія «Христос» - масштабний (біля трьох годин; 4 солісти, дитячий та дорослий хори, орган і оркестр) твір з використанням біблійних та літургійних текстів, скорботою і заключним славінням буття кореспондує з такими «колосами» ораторіального жанру, як «Історії Різдва Христова» Г. Шютца (1664), «Різдвяна ораторія» Й. С. Баха (власне цикл церковних кантат, які виконувались протягом усіх святок, 1734), «Месія» Г. Генделя (1741), «Христос» (1847) і «Дитинство Христа» Г. Берліоза (1853-1854), «Різдвяні ораторії» К. Сен-Санса (1858) і у XXI ст. (2008) - арх. Іларіона (Алфєєва). Релігійно-філософська концепція і композиція лістівської ораторії стають «провіщенням нової містерії» як «одного з найбільш ранніх проявів тенденції, що розкрилася в мистецтві першої третини XX століття» [5, с. 12, 6]. Закономірні для віруючого з дитячих років Ліста (до того ж підсилені обставинами особистого життя) ухвалення обітниці та свячення в сан абата 1865 року (ораторія «Христос» закінчена у 1866) віддзеркалюють ту функцію митця-християнина (славити Бога безпосередньо своєю справою) - у духовних жанрах і не тільки, як її розумів романтик Ліст. Відповідно до ідейно-художніх настанов своєї епохи біблійні сюжети і символи композитор подає крізь призму романтичного світосприйняття і світорозуміння з увагою до суб'єкта, героя, що є виразником художнього світу цієї епохи. Бо творець-романтик уподібнюється Богу-творцю, стаючи його своєрідним «дзер- 
кальним відображенням... романтизм є ні чим іншим, ніж розвитком (аж до прямого переходу на противагу) деяких сутнісних рис, властивих християнському світовідчуттю у цілому» [6, с. 84]. Звідси й розуміння мистецтва як «одного з найсильніших засобів морального впливу на суспільство» і сприйняття його «в безпосередньому зв'язку з релігією» [9, с. 71], що знайшло відтворення, зокрема, в ораторіях Ліста, де «автор порушує вічні питання сенсу земного буття, добра і зла, очищення душі і спасіння... він інтерпретує ці образи перш за все як композитор-романтик з його прагненням показати всі етапи життєвого шляху героїв - від народження до смерті - очима самих героїв» [9, с. 71], а також в його фортепіанних творах (й у життєвих обставинах). Симптоматичними виступають з цієї точки зору назви ораторій представника барокової епохи - Г. Генделя («Месія») і романтичної - Ф. Ліста («Христос»). Перший подає Ісуса як помазаника Божого, виконуючого Призначення Спасіння; Ліст акцентує - через ім'я - особистість Спасителя, передаючи філософське значення романтизму, шо «складається, перш за все, у його спробах виявити в спонтанних рухах душі митця, переживаючого світ, позамежне приховані фундаментальні шари буття» [15, с. 29]. У фортепіанному циклі «Різдвяна ялинка» Ліст йде ще далі у передачі таких спонтанних рухів, позначаючи у назві традиційний атрибут земного святкування Різдва, призначений, перш за все, дітям (формування різдвяного ритуалу відносять, знов таки, до початку Нового часу, як і «народження дитинства»), який символізує також епізод поклоніння волхвів (північний гість, за легендою, приніс серед дарів і ялину); i «піхта християнства Святого Боніфатія», що виросла на коренях «зрубаного дуба язичництва» [17], й інші давні легенди. Але одночасно композитор явно передбачає у програмному змісті циклу й біблійний концепт Різдва (євангельські сцени у колисці Святого Немовляти; рефлексивні звороти до церковних дзвонів; звернення до мотивів старих різдвяних пісень). Характерно, шо у єдиному номері, власне присвяченому ялинці (№ 5 «Запалюють ялинку»), явно споглядається музично-мовне перегукування з церковними дзвонами, а сама назва вказує також на зворотний зв'язок дитячого світу з дорослим (дорослі «запалюють» для дітей). Таким чином, визначення Ліста як «композитора-філософа» чудово укладається в епохальні настанови, коли «не тільки філософи... але й... музиканти намагаються по-новому визначити зміст і значення музики», «відбувається переосмислення художньої творчості в цілому, поступове «прозріння» його онтологічного статусу», 
«результат творчості розглядається тут цілком онтологічно» [15, с. 29]. Така тенденція позначилася і на музичному «стрижні» митця, роялі не культовому за своїми походженням та природою, в низці номерів у фортепіанних циклах «Поетичні та релігійні гармонії» і «Різдвяна ялинка», фортепіанних п'єсах «Alleluia», «Sancta Dorothea», «In festo transfigurationis», «Sursum corda» та ін.

Слід відзначити, що інструментальні твори духовного змісту, у тому числі присвячені Різдву, сягають корінням ще у XVI століття (святочна вокально-інструментальна музика Преторіуса та ді Лассо) і являють обробки різдвяних пісень - англійських керолс, французьких ноелей і т. п. В XVII ст. серед чисельних Concerti grossi виявляються так звані «Різдвяні концерти». Один з перших їх авторів А. Кореллі (ор. 6, № 8), список продовжили А. Скарлатті, А. Вівальді, Дж. Тореллі, Ф. Манфредіні, П. Локателлі, Л. Заватері, Ф. Барсанді, Д. Саммартіні, П. Антоначчі, Ч. Авізон, Й. Пец, Г. Телеман, П. Хеллендел, Й. Мольтер. Відомі «Різдвяні сюїти» М. Коррета та Ф. Госсека, а також «Різдвяні симфонії» М. Делаланда, М. Коррета (XVIII ст.), вже у XX ст. «пролонговані» у фортепіанному циклі О. Мессіана «Двадцять поглядів на Немовля Ісуса» (1944), симфонії № 2 «Різдвяна» (1980) К. Пендерецького, симфонічній поемі «Сочельник» («Christmas Eve», 1912) англійського композитора А. Бакса, сюїті «Life without Christmas» (1990-1992) Г. Канчелі та ін. Але особлива роль у музичній «інструменталізації» теми Різдва, безперечно, відводиться органним та клавірним французьким ноелям XVII-XVIII ст. (на цей період припадає й розквіт ораторіального жанру, у тому числі «різдвяного»). В основі сольно-інструментальних ноелів лежить серія варіацій сюїтного плану на тему різдвяних піснеспівів, і вони стають одним з улюблених жанрів композиторів французького органного бароко - Н. Жіго, Н. Льобег, А. Резон, П. Дандрійо, М. Корретто, Ж.-Ф. Дандрійо, Л. Дакен, К. Бальбастр, Ж.-Ж. Боварле-Шарпантьє, Г. Лассьо. Літургійна від початку трактовка органного ноелю не тільки поступово трансформується у «концертну» (з'являються вказівки щодо виконання на клавесинах, піанофорте, оркестрових інструментах з відповідними концертно-виконавськими ознаками емоційного тонусу, яскравості, віртуозності та слухацькими оплесками й спеціальними концертними анонсами - аж до заперечень знаменитому Бальбастру їх виконання під час меси [16, с. 44]), а й привносить до кінця XVIII ст. «до літургійного контексту незаперечні ознаки нового концертного стилю» [16, с. 44]. 
Така тенденція «музичної Різдвіяни» практично співпадає за часом 3 «відкриттям дитинства» (власне, з християнським культом Немовляти-Ісуса й повязує Ф. Арьєс новий етап відношення до дитини й дитинства). На думку Ф. Арьєса, саме у XIX столітті дитинство стає «привілейованим віком» [1, с. 42], дорогоцінним «світом у собі». 3 романтиків починаються «дитячі діти, їх цінують самих по собі, а не в якості кандидатів у майбутні дорослі. Якщо говорити мовою Фрідріха Шлегеля, то в дітях нам дана як би етимологізація самого життя, в них ії першослово... У дітях максимум можливостей, які розсіюються і губляться пізніше. Увага романтиків спрямована до того в дітях і в дитячій свідомості, що буде втрачено дорослими» [2, с. 42]. Недивно, що саме у добу романтизму, «на перехресті різноманітних пластів і сфер музичної культури» викристалізовується таке самобутнє явище як авторський фортепіанний Дитячий альбом, якому притаманні «дихотомічні зв’язки: а) професійної композиції та побутового музикування; б) багатовікової традиції музичного викладання та яскравої особистості класиків; в) дидактичних завдань, простоти фактури та найактуальніших для музичного мистецтва образів та жанрів» [3, с. 12], накладання світів дитячого та дорослого. Цікавість до цього специфічного циклу мініатюр тільки посилюється на зламі XIX-XX століть аж до XXI, відбиваючи соціокультурні настанови своєї епохи щодо дитинства і дитячості. Третє сторіччя поспіль у європейській професійній музиці покоління композиторів пропонують свої варіанти прочитання подібних циклів мініатюр як «свідчення особливого поетичного світовідчуття їх авторів, майстерності мислити афористично, влучно, в лаконічних композиційних формах, до того ж за умов суворої економії засобів виразності» [3, с. 12]. Від «Нотних книжечок» Й. С. Баха, «Лондонського зошиту» восьмирічного В. Моцарта, «Багателей» Л. Бетховена через «Різдвяний альбом» ор. 72 Ф. Мендельсона, «Дитячі сцени» ор. 15 і «Альбом для юнацтва» ор. 68 Р. Шумана, «Різдвяну ялинку» Ф. Ліста, дитячі фортепіанні цикли П. Чайковського, К. Дебюссі, С. Борткевича, А. Лур'є, М. Метнера, В. Рєбікова, М. Равеля. Б. Бартока, 3. Кодая аж до С. Прокоф'єва, Д. Шостаковича, В. Косенка, Е. Денісова, В. Сільвестрова, С. Губайдуліної та інших оновлюється композиторська поетика дитячих циклів, виявляючи парадокси у одночасному контрасті «дорослого та дитячого, простого та складного, реального та символічного, наївного та мудрого» [3, с. 13], нарешті земного та Небесного. У цьому сенсі різдвяна тематика виділяється рисами піднесеності, узагальненості (у тому числі через жанр), 
репрезентацією квінтесенції дитячості через культ Немовляти Ісуса, зв'язком образу дітей з темою Різдва як домашнього свята [3, с. 30].

Першим таким зразком у жанрі фортепіанного циклу для дітей слід вважати «Різдвяний альбом» ор. 72 Ф. Мендельсона, де власне сформувалися риси, характерні для поетики романтичного Дитячого альбому в цілому: зв'язок дитячої образності з темою Різдва; втілення музичних смаків епохи в інтонаційній будові, фактурі, гармонії, жанрових настановах; узагальнення через жанр - хорал, «пісня без слів», марш, танцювальність, художній етюд; утвердження у зв'язку з дитячою образністю скерцозності як семантичної сфери гри; характерний для Дитячих альбомов дидактичний нахил «від простого до складного; взаємозв'язок поетики циклу з духовним світом автора» [3, с. 30-31]. У Р. Шумана, який вважав дитячі твори втіленням поетичної сутності романтизму, наявні вже «практично всі жанрові різновиди дитячої музики, що склалися на той час: танцювальні сюїти, зібрання вокальних та інструментальних мініатюр, легкі сонати та сонатини» 3 «істотним оновленням музичної поетики» [3, с. 30-31]. Слід зазначити, що «Альбом для юнацтва» ор. 68 Р. Шумана спочатку називався «Різдвяний альбом». Цікаво, що на Ліста він справив неабияке враження у листі від 5 червня 1849 року той написав Р. Шуману: «Ваш «Альбом для юнацтва»... мені - мало сказати - дуже подобається!» (цит. за: [3, c. 88]). Саме у Шумана викристалізувався формат втілення теми дитинства в музиці через циклічну форму, «мініатюри якої зручні у вибірковому порядку для методичної роботи, а при виконанні як цикла утворюють багатошаровий підтекст складного художнього твору», де викладення дитячих образів виступає «у щільному зв'язку з подіями та враженнями особистого характеру» [3, с. 90-91].

Взагалі Різдвяний сюжет є надзвичайно багатозначним. I якщо «В канонічних рамках богослужіння всі ці смисли існують в одночасності та цілісній єдності, то спроба їх інтерпретації в художній творчості тягне за собою можливість їх переакцентування, зміни смислових домінант» [4, с. 46], тим паче у циклі інструментальних мініатюр для дітей (кожна складова цього жанру вже передбачає багатошаровість). Цікаво, що теми Різдва і дитинства в музиці XIX ст. «починають тісно взаємодіяти між собою - аж до того, що А. Булкін приходить до висновку про їх нерозривний зв'язок в циклічних композиціях» [4, c. 48]. Настановами вказаної взаємодії позначені «Дитячі народні пісні» Й. Брамса, п’єси «3 дитячого життя» Т. Куллака та інші. У цьому ряду гідне місце посідає і цикл «Різдвяна ялинка» Ф. Ліста. 
У циклі «Різдвяна ялинка» проглядає романтична ідея сприйняття дітей як представників-символів ідеального світу, протиставленого у своїх проявах невинності і безпосередності перекрученому та холодному світові розсудливої дорослості. Адже художня свідомість будь-якого автора вміщує «міфологічну «легенду», або «колективне несвідоме», яке виконує по відношенню до його творіння роль поетологічного коду», за допомогою якого «можна значно поглибити безпосередній зміст твору, виявивши в ньому інший - міфологічний - сенс, який не тільки актуалізує минуле в сьогоденні, але i сприяє тому, щоб в цьому відгукнулося нікому не відоме майбутнє» $[11$, c. 63]. Але якщо звичайно романтичний культ ідеалізованого дитинства не містив в собі інтересу до психології справжньої, живої дитини, то у «Ялинці» Ліст знову виступає новатором, що закидає у майбутне, XX століття, яке вчені називають «століттям дитини» (Е. Кей), де дитинство - «самостійний об’єкт аналізу в філософсько-культурологічних» [12, с. 13], психологічних, етнологічних, соціологічних, мистецтвознавчих та інших дослідженнях. Ліст вибудовує низку характерних «ілюстрацій» різдвяної історії, приводячи свій цикл від стриманого церковно-хорального жанру (навіть з «вербальною підтекстовкою» старовинних різдвяних песень у № 1, 2, 4, що К. Зенкін розглядає як «максимальну присутність слова в інструментальному творі, у порівнянні з програмним заголовком або поетичним епіграфом» [7, с. 352]), своєрідної «домашньої містерії» (за А. Булкіним [3, c. 89]) до вельми екстатичної, «далекої» від звичайного молитовного настрою, по-карнавальному земної радості первинних танцювальних жанрів (святкова хода № 11,12), у музичному плані вираженої нарощуванням концертності та артистизму. Такий драматургічний хід (від «містеріальності» до «суб'єктивної творчої фантазії» [3, с. 90]) утворює «романтично-ідеальну конструкцію прикладної Hausmusik, а точніше, самий перехід, модуляцію побутового у чисте мистецтво». К. Зенкін вказує, що «Різдвяну ялинку» однаково легко і у той же час важко уявити звучною як в домашній обстановці, так і на концерті - мабуть, ії можна було б уявити лише у будинку самого Ліста» [7, c. 152-153] - великого артиста і монаха (можливо, у цьому криється і таємниця нечастого виконання циклу). Подібна «сюжетна програмність» (характерна й для «Років мандрів», й для симфонічних творів композитора) сприяє наближенню до справжнього життя, в даному випадку до «живої дитини» - іманентно віруючої, непорочної та артистично-грайливої, «живої» - одночасно (саме такий тандем 
виявляв і сам Ліст у собі та інших). Такий «універсальний світ, який виявляється здатним зачепити зацікавленість не тільки дітей, представляючи, «одночасно «музику для дітей» та «музику для дорослих» [14, с. 354], стає використованим для втілення у фортепіанних циклах вже XX століття. Характерно, що вони часто виконуються дорослими, іменитими піаністами. Так, «Ялинку» Ліста виконували Ф. Бузоні, К. Ігумнов, А. Брендель, В. Горовиць, О. Любимов, У. Маршалл, Л. Ховард, Е. Брійє та ін. Ліст демонструє у циклі поєднання ігрових інтенцій дитячості з «дорослими» якостями духовних настанов у конкретиці біблійної тематики. Специфіка лістівського програмного методу у «Ялинці» відзначається «вражаюче-чутливою, «мембранною» музичною реакцією на поетичне джерело» [8, с. 11], у даному разі - біблійне джерело. Цикл «Різдвяна ялинка» своєрідно відбиває значну частину іiі філософсько-теологічних проблем і пов'язаний 3 ключовою подією біблійного епосу - народженням Божественного Немовляти. Дитячому сприйняттю реальності безпосередньо і первинно притаманні естетичні і духовні (з урахуванням вказівки самого Христа на близкість дітей до Бога - «будьте як діти») категорії гармонії, краси, гри, святковості, чистоти. Все це якнайкраще відповідає смисловим посилам обраної у циклі теми - Різдва Христова і певним композиційним, жанрово-стилістичним, музично-мовним, піаністичним принципам. При втіленні сюжетних ситуацій, «зримих», навіть театралізованих (але й архаїчно-містеріальних), мініатюр, композитор звертається до різноманітних жанрових характеристик: хоральності (№ 1, 2, 4), танцювальності (№ 3, 12), токатності (№ 5), баркарольності (№ 7), скерцозності (№ 5, 6), прелюдійності (№ 6, 9), маршовості (№ 1, 2, 4, 8, 11), колисковості (№ 7), баладності, вальсовості (№ 10), полонезності-мазурковості (№ 12).

К. Зенкін зазначає, що Ліст тут «забуває не лише про віртуозність, але іноді навіть про саму фортепіанність» [7, с. 23]. Так, перші чотири п’єси можуть бути виконані також і на фісгармонії, або з голосом (голосами № 1, 2, 4), перші дві - мають хорову, хоральну фактуру (з інструментальним басовим супроводом у № 1), № 3 і 4 - живописні жанрові картинки («Пастухи біля ясел» та «Поклоніння волхвів»), але з біблійнної історії. Всі чотири разом утворюють вказану вище «домашню містерію». Своєрідним лунанням-аркою до неї виступає № 8 («Стара провансальська різдвяна пісня») - ії вміщення всередині «земного блоку» (№ 5-12) разом з № 7 («Колисковою») може бути сприйнятим як «пісенна» («мовна») його власна середин- 
ка і своєрідне «неземне» нагадування «земному» світові. Інша арка створюється між № 6 і 9, де колористично-імпресіоністичні фортепіанно-інструментальні звукообрази звучних церковних дзвонів одночасно є символом храмового простору, у святковій атмосфері Різдва у даному випадку (тобто - додаткова «арка» 3 першим блоком 3 чотирьох номерів) - власне всередені цієї арки і вміщуються № 7, 8 . Таким чином, проростання концертності «земного свята» в останніх двох номерах (концертно-святкові ходи «Угорського маршу» та «Польського») відбувається поступово - через амбівалентну дієвість середнього блоку (№ 5-10) з його більш земними (пісенно-мовними або характерно-ігровими) нахилами № 5, 7, 10 та різдвяно-храмовими маркерами № 6, 8, 9. Власне дієвість (земна, домашня, поступово концертна) починається з № 5, присвяченого «герою», що дав назву усьому циклу. Ялинка «запалюється» (що символізує початок земного святкування удома - 3 подарунками, сладощами, демонстрацією любові до близьких, «відчуття дитинства») у скерцозному характеpi, темпі Presto, «лунанням» тональних $(\mathrm{F} / \mathrm{d})$, динамічних ( , cresc., $\operatorname{dim} ., m f, f f, p p)$, тембрально-імпресіоністичних звукових барв, ніби «задаючи тон» таким імпресіоністичним фарбам й самому церковному дзвонові, що продовжує святкове «мерехтіння» у «справжньому» колективному передзоні № 6. Заключний блок (№ 11, 12) - яскраві жанрові святкові картинки з вираженими ритмоформулами (угорського маршу й польської мазурки), концертними масштабністю подання фортепіано та розробковою свободою, нарешті - національно актуальними, цілком романтичними мотивами. Подібна арочно-наскрізна композиційна структура сприяє цілісності циклу, але важливим у його виконанні виступає «жива» виконавська складова: Ліст (як і діти з їх здатністю до нескінченних творчо-ігрових ситуативних рішень) - виконавці «по крові». Близкість природи мистецтва, зокрема музичного, і дитячості уособлюється й у накладанні (цілісності) двох протилежних інтененцій: сакралізації, ідеалізації дитячого світу (як вічного, ідеального) та ігрового начала (як швидкоплинного та як відходу від складних буттєвих проблем).

Таким чином, символічна цілісність циклу Ф. Ліста «Різдвяна ялинка» вказує на найдавнішу міфологему сутності світу і людського життя - прилучення людини до Вічності і Безсмертя з первинним пограничним станом народжуваного немовляти 3 неодмінним подальшим новим духовним народженням. Розкриваючи смисловий зміст такої символіки, необхідно враховувати безсумнівне концеп- 
туальне значення ідеї Бога в творчості і житті Ф. Ліста. Можливо, у свідомості (і підсвідомості) автора - мислителя і композитора - apхетип Спасителя, «дорослого Христа» збігається з архетипом Божественного Немовляти, створюючи єдиний образ, який символізує вічно відроджуваний Дух. Звідти в образній палітрі циклу поєднуються «дорослі» смисли-образи молитви, церковної атмосфери з передзвонами, біблійних сцен - 3 «дитячістю» святкових подій, відчуття дива, де дитячість, дитинство виступають як джерела оновлення та узагальнено-всеосяжного добра у зворушливій конкретиці своїх проявів.

У самій присвяті циклу любій онуці та адресній спрямованості музики дітям здійснюється своєрідна проекція міфопоетичної конструкції «батько - син», втіленої у центральній християнській історії смерті і воскресіння Христа і відтвореної в Свангельських переказах. Таким чином, створюється авторський, лістівський «міф» про смерть, відродження (воскресіння), продовження роду, в основі якого знаходиться відома архетипова структура. А духовне наслідування у дітях/онуках (подібне до подовження Отця через Сина) долає емпіричний час.

3 іншого боку, невтомний новатор у музиці, Ліст демонструє у дитячому циклі «Різдвяна ялинка» інструментально-фактурні та гармонічні прийоми, які невдовзі стануть маркерами імпресіоністського звукопису. Особливо це помітне у «церковних» п’єсах - № 6 «Дзвоновий передзвін», № 9 «Вечірній дзвін», у поетично-інтимній «Колисковій» № 7 та ін. У «дитячій» простоті циклу вбачається рука великого Майстра, який в імпресіоністській «мазковій» манері здатний обдарувати слухача відчуттям проникаючої в душу безтурботності, гри, по-дитячому щирої, дивної святковості та всюдисущої Вічності, Божественної гармонії й чистоти.

Взагалі-то Ліст, цілком «дорослий» митець - емоційний «не подитячому» аж до «мефісто», умудрений філософ-концептуаліст зі складними «дорослими» питаннями буття (життя й смерті, Творця і Бога, мистецтва і його творця), неперевершений виконавець свого часу, який зумів пролонгувати свої виконавські, композиторські, музикознавчі, філософські настанови у майбутнє століття, все життя «працюючий» на дорослу аудиторію, - дійшов при кінці земного буття тої дитячої безпосередньості розуміння Істини, «геніального спрощення» композиторської мови, що своєрідно проекується на відомому ситуацію Христа з дітьми.

Власне, вихід на перший план теми «митець і Творець» остаточно стверджується у фортепіанних програмних циклах наприкінці XX 
століття $[10$, с. 7], в зв'язку з чим пріоритетними стають сакральні образи (Ліст і тут виступає «музичним провидцем»). Структура окремих п'єс часом визначається логікою розвитку церковного звучання, в зв'язку з цим виникають особливі різновиди тричастинної форми. Характерним є розкриття кантиленних якостей інструменту - «співаючого» фортепіано» «сакральне і театрально-ігрове в сучасному циклі програмних п’єс є двома полюсами художнього і музичного змісту, кожен зі своїм комплексом виражальних засобів» [10, с. 9]. I це «стрибок» Ліста у кінець ХХ століття. Лістівська «Різдвяна ялинка» відрізняється специфічно романтичним поєднанням ідеального і земного-реального (дитячого/дорослого) світів, явним духовним нахилом, барвисто(заково)-психолоічними характеристиками. Останні дві позиції «належать», скоріше, вже до рис наступного, XX століття.

Цілісна циклічна форма «Ялинки» дозволяє виявити низку особливих властивостей iї форми-змісту, шо спонукає до аналізу музичного матеріалу з позицій виявлення і взаємодії таких параметрів: смислового (в програмі), конструктивного (в будові), жанрового (виходячи з характеру і музичних засобів вираження) і просторово-часового (у реальному звучанні й звукозображальних ефектах). Смисловий параметр вирізняється амбівалентністю сакрального/театрально-ігрового: христологічна лінія виявляє диво Народження Немовляти, сили Бога, Надію, що несе це Народження; святково-ігрова демонструє земні радощі, неодмінно освячені Божественним Немовлям, а також земні радощі дитинства (у тому числі «дорослого дитинства» у відчутті дива-свята) як категорії, наближеної до Бога. Вказані характеристики цілісності по-своєму відтворюють і цілісність дитячого світосприйняття, яке вдалося зберегти умудреному митцю.

\section{СПИСОК ЛІТЕРАТУРИ}

1. Арьес Ф. Ребенок и семейная жизнь при Старом порядке / Ф. Арьес. Екатеринбург : Изд-во Урал. ун-та, 1999. - 416 с.

2. Берковский Н. Романтизм в Германии / Н. Я. Берковский. - Л. : Художественная лит-ра, Ленингр. отд-ние, 1973. - 129 с.

3. Булкин А. Фортепианный детский альбом : пути становления, поэтика жанра : дис. .... канд. искусствоведения : 17.00.03 / Арнорльд Ильич Булкин. K., 2005. - $162 \mathrm{c}$.

4. Вороніна М. Особливості трактування євангельських сюжетів у французькій ораторії другої половини XIX ст. крізь призму історії жанру («Дитинство Христа» Г. Берліоза та «Марія Магдалина» Ж. Массне) : дис. ... канд. мист. : 17.00.03 / Марія Олексіївна Вороніна. - К., 2017. - 204 с. 
5. Горбунова О. Религиозная проблематика в философско-эстетической эволюции Ф. Листа : автореф. дис. ... канд. искусствоведения : спец. 17.00.09 «Теория и история искусства» / О. П. Горбунова. - Саратов, 2013. - 16 с.

6. Зенкин К. Романтизм в контексте христианской культуры / К. В. Зенкин // Музыкальная культура христианского мира : [матер. междунар. науч. конф.]. - Ростов-на-Дону, 2001. - С. 83-94.

7. Зенкин К. В. Фортепианная миниатюра и пути музыкального романтизма / К. В. Зенкин. - М., 1997. - 415 с.

8. Коваль Г. Ліст і Данте: до проблеми синтезу мистецтв : автореф. дис. ... канд. мист. : спец. 17.00.03 «Музичне мистецтво» / Г. О. Коваль. - К., 1998. $16 \mathrm{c}$.

9. Кривеженко В. С. Трактовка христианских образов в свете религиознофилософских взглядов Ф. Листа (на примере ораторий «Легенда о Св. Елизавете» И «Христос») / В. С. Кривеженко // Проблемы музыкальной науки : [сб. науч. статей / Уфимский государственный институт искусств им. Загира Исмагилова]. - Уфа, 2010. - № 2. - С. 70-72.

10. Лебедева В. Цикл программных пьес и прелюдий в русской фортепианной музыке XX века: традиции и новые тенденции : автореф. дис. ... канд. искусствоведения : спец. 17.00.02 «Музыкальное искусство» / В. В. Лебедева. - М., 2008. -20 с.

11. Пустошкина Т. «Дитя больше, чем оно есть...» (мифологема детства в нравоучительной повести А. Погорельского «Черная курица, или Подземные жители») / Т. В. Пустошкина // Вестник Санкт-Петербургского университета. Сер. 9 : [науч.-теор. журнал]. - СПб., 2007. - Вып. 3, ч. II. - С. 62-67.

12. Суворкина Е. Морфология субкультуры детства : автореф. дис. ... канд. культурологии : спец. 24.00 .01 «Теория и история культуры» / Е. Н. Суворкина. - СПб., 2014. - 29 с.

13. Титова С. Фортепианный цикл Ф. Листа «Рождественская ёлка» / С. С. Титова // Молодой ученый. - 2012. - № 7. - С. 351-353.

14. Титова С. Фортепианный цикл для детей второй половины XX века (на примере художественного языка и композиции «Музыкальных игрушек» С. А. Губайдулиной) / С. С. Титова // Молодой ученый. - 2012. - № 7. C. $353-355$.

15. Фомина 3. Сущность музыкального в интерпретациях мастеров романтизма (онтологический аспект) / 3. В. Фомина // Проблемы музыкальной науки : [сб. статей / гл. ред. Л. Н. Шаймухаметова]. - Уфа, 2012. - 1 (10). C. $28-31$.

16. Чебуркина М. Ноэль французского органного барокко как синтез литургических и светских тенденций / М. Н. Чебуркина // Проблемы музыкальной науки : [сб. статей / гл. ред. Л. Н. Шаймухаметова]. - Уфа, 2012. № 2 (11). - C. 43-46.

17. Lozza L. The Christmas Tree: Legends, Traditions, History [Електронний pecypc]. - Режим доступу : http://www.ewtn.com/library/chistory/xmastree.htm 
Чжу Сяоле. Фортепианный цикл Ф. Листа «Рождественская елка»: новая конщепция детской музыки. В статье выявляются смысловые пласты фортепианного цикла Ф. Листа «Рождественская елка» в аспектах «открытия детства», музыкальной Рождествениады, языково-композиторских, композиционных и духовно-философских основ, что позволяет выявить ряд особых свойств формы-содержания цикла, а также побуждает к анализу музыкального материала с позиций амбивалентности сакрального/театрально-игрового. Последнее воспроизводит целостность детского мировосприятия, которое удалось сохранить умудрённому художнику - Ф. Листу - до конца жизни.

Ключевые слова: фортепианный цикл для детей, «открытие детства», романтизм, Ф. Лист, рождественская тема в музыке.

Zhu Xiaole. F. Fista's piano cycle «Christmas tree»: a new concept of children's music. In the article, the semantic layers of F. Lisz's piano cycle «Christmas tree» are revealed in the aspects of the «discovery of childhood», the musical Christmas theme, the linguistic-compositional, compositional and spiritual-philosophical foundations, which makes it possible to identify a number of special properties of the form-content of the cycle, motivates the analysis of musical material from the point of ambivalence of the sacral / theatrical-playing. The last one reproduces the integrity of the child's worldview, which the wise artist F. Liszt managed to preserve until the end of his life.

Keywords: piano cycle for children, «the discovery of childhood», romanticism, F. Liszt, Christmas theme in music.

Стаття надійщла до редакції 04.05.2016

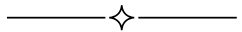

